\title{
Design of ionic liquid-based microwave-assisted extraction of flavonoids from Cyclea barbata Miers. and its lipoxygenase inhibitory activity
}

\author{
Islamudin $\mathrm{Ahmad}^{1 *}$, Berna Elya ${ }^{2 *}$, Yayuk Isneyni Ismail ${ }^{2}$, Arikadia Noviani ${ }^{2}$, Hadi Kuncoro ${ }^{1}$, Maryono ${ }^{3}$, Neneng Siti Silfi \\ Ambarwati ${ }^{4}$ \\ ${ }^{1}$ Department of Pharmaceutical Sciences, Faculty of Pharmacy, Mulawarman University, Kampus UNMUL Samarinda, East Kalimantan, Indonesia. \\ ${ }^{2}$ Department of Pharmacognosy-Phytochemistry, Faculty of Pharmacy, Universitas Indonesia, Kampus UI Depok, West Java, Indonesia. \\ ${ }^{3}$ Department of Chemistry, Faculty of Mathematics and Natural Sciences, Universitas Negeri Makassar, Makassar, South Sulawesi, Indonesia. \\ ${ }^{4}$ Department of Cosmetology, Faculty of Engineering, Universitas Negeri Jakarta, East Jakarta, Indonesia.
}

\begin{tabular}{l}
\hline ARTICLE INFO \\
\hline Received on:03/08/2019 \\
Accepted on: 22/12/2019 \\
Available online: 04/04/2020 \\
\hline Key words: \\
Cyclea barbata Miers., ionic \\
liquid-microwave assisted \\
extraction, response surface \\
methodology, total flavonoid \\
content, lipoxygenase activity \\
inhibition.
\end{tabular}

inhibition.

\begin{abstract}
Green grass jelly (Cyclea barbata Miers.) is a plant from Indonesia that is believed to have anti-inflammatory activity. This study aims to find the optimum condition in grass jelly extraction using the ionic liquid-microwave assisted extraction toward total flavonoid content (TFC) and lipoxygenase activity (LIA). The experimental design was performed using the parameters variable including extraction time, liquid-solid ratio, and ionic liquids concentration to obtain the optimum condition. The optimization analysis used response surface methodology (RSM) with BoxBehnken design (17 trials) to obtain a predictive model with TFC and LIA as a response surface value. In the present study, the optimum condition was suggested by RSM analysis with parameter variables, including extraction time of 17 minutes, 1-butyl-3-methylimidazolium bromide ([BMIM]Br) concentration of $1.76 \mathrm{~mol} / \mathrm{l}$, and the liquid-solid ratio of $38.21 \mathrm{ml} / \mathrm{g}$. The equation of regression quadratic model was obtained to predict TFC and LIA as follows: TFC = $2.43 \mathrm{~A}+2.43 \mathrm{~B}+1.42 \mathrm{C}+0.33 \mathrm{AB}-3.20 \mathrm{AC}-0.46 \mathrm{BC}-4.90 \mathrm{~A} 2-3.10 \mathrm{~B}^{2}-3.10 \mathrm{C}^{2}+28.32$ with $R^{2}=0.8336$ and LIA $=0.066 \mathrm{~A}+8.22 \mathrm{~B}+0.97 \mathrm{C}+2.47 \mathrm{AB}-5.86 \mathrm{AC}+1.96 \mathrm{BC}-9.99 \mathrm{~A}^{2}-13.75 \mathrm{~B}^{2}-13.11 \mathrm{C}^{2}+63.53$ with $R^{2}=0.9207$, respectively.
\end{abstract}

\section{INTRODUCTION}

Green grass jelly (Cyclea barbata Miers.) is a species of Menispermaceae family which is widespread and utilized by people in many parts of Asia such as Indonesia, Thailand, India, and Burma. In Java and Sumatra island of Indonesia, the local community traditionally uses this plant as an anti-inflammatory (Siregar and Miladiyah, 2011). Some research has stated that the

\section{${ }^{*}$ Corresponding Author}

Islamudin Ahmad, Department of Pharmaceutical Sciences, Faculty of Pharmacy, Mulawarman University, Kampus UNMUL Samarinda, East Kalimantan, Indonesia.E-mail: islamudinahmad@farmasi.unmul.ac.id; Berna Elya, Department of Pharmacognosy-Phytochemistry, Faculty of Pharmacy, Universitas Indonesia, Kampus UI Depok, West Java, Indonesia.E-mail: berna.elya@gmail.com green grass jelly leaves contain phenolic compounds (Arkarapanthu et al., 2005; Sahasakul et al., 2015) flavonoids (flavonol), saponins (Kusmardiyani et al., 2014), rich in pectin (Hertanto et al., 2017; Yuliarti et al., 2017) and nutrients (Sahasakul et al., 2015). In general, flavonoids have anti-inflammatory activities as described by Kumar and Pandey (2013).

Inflammation is the body's response to dangerous conditions such as infections and tissue injuries to maintain homeostasis (Medzhitov, 2008). Arachidonic acid metabolism influences inflammatory mechanisms through two pathways: lipoxygenase (LOX) and cyclooxygenase (COX). Both these pathways produce the biological mediators of inflammation including leukotriene, prostaglandin, and thromboxane (Akula and Odhav, 2008).

Conventional extraction methods take a long time and have low efficiency, and also uses excessive organic solvents 
(Azmir et al., 2013; Bubalo et al., 2014; Carda-broch et al., 2008). As the process of extraction develops, many new extraction methods use fewer solvents and consider the efficiency of the extraction time (Azmir et al., 2013; Tang et al., 2012; Wang et al., 2011). Recently, alternative solvents have been found that can replace organic solvents that are low-volatile ionic liquids, capable of dissolving specific compounds, heat-stable, and non-flammable (Chemat et al., 2012). An ionic liquid as a green solvent can be combined with non-conventional extraction methods, mainly using microwave-assisted extraction methods (IL-MAE) (Chemat and Vian, 2014). Some studies have reported that the IL-MAE method successfully extracts secondary metabolite compounds optimally including flavonoid group (Ahmad et al., 2017b; Tang et al., 2013; Wei et al., 2012; Zhang et al., 2014; 2015).

However, the studies related to optimization and application of green extraction using the IL-MAE method and research on inhibition of the lipoxygenase activity from green grass jelly leaves have not been reported. Therefore, this study contributes to the knowledge of the extraction engineering of secondary metabolite and biological properties of this plant. This study aimed to obtain an optimal IL-MAE method to the extraction of flavonoids from green grass jelly leaves and investigate its lipoxygenase inhibitory activity.

\section{MATERIALS AND METHODS}

\section{Plant materials}

Green grass jelly leaves were obtained from Bogor, West Java, Indonesia and was identified at Laboratory of Biosystematics, Indonesian Institute of Science (Lembaga Ilmu Pengetahuan Indonesia) Cibinong, West Java, Indonesia. The sample specimen (DC-001984-F) was collected at the Laboratory of Pharmacognosy-Phytochemistry, Faculty of Pharmacy, Universitas Indonesia, Depok, West Java, Indonesia.

\section{Chemicals and equipment}

Chemicals and equipment used in the study, includes Lipoxygenase kit and linoleate acid, were purchased from Sigma Aldrich. Boric acid, sodium acetate, potassium chloride, sodium hydroxide, and aluminum chloride were bought from Merck, Germany (via PT. Elo Karsa Utama, Indonesia). Aqua DM, ethanol for analysis, methanol for analysis, ethyl acetate for analysis, and ethyl acetate were purchased from PT SmartLab Indonesia, Indonesia. 1-butyl-3-methylimidazolium bromide ([BMIM]Br) was purchased from Shanghai Cheng Jie Chemical Co. LTD, China. Design Expert v10 licensed software (STATEEASE), spectrophotometer UV-Vis (Jasco V-530, Japan), Modena Microwave 900 Watt (Buono-MV3002), Vortex mixer (Stuart, Germany), Analytical scales (Sartorius 7, Germany), sonicator (Krisbow, Indonesia), micropipette 10-100 $\mu 1$ and 100-1,000 $\mu 1$ (Corning), and $\mathrm{pH}$ meter (Eutech Instrument, French).

\section{Ionic liquid-based microwave-assisted extraction procedure}

The IL-MAE method was performed based on literature (Ahmad et al., 2017a; 2017b), with a slight modification. Briefly, a $0.5 \mathrm{~g}$ of the dried sample of Green grass jelly leaves were extracted using [BMIM]Br solvent in the microwave (Modena $900 \mathrm{~W}$ ) with some conditions as can be seen in Table 1. The separation of the residue and the extract solution was conducted by filtration. The filtrate (extract) was cooled and left for 10-12 hours at the room temperature. Then, the filtrate was partitioned with liquid-liquid extraction using ethyl acetate. The ethyl acetate layers were separated and evaporated to obtain the dried extracts.

\section{Determination of total flavonoid content}

The total flavonoid content (TFC) of each extract was analyzed by aluminum chloride colorimetry method based on literature (Baba and Malik, 2015; Chang et al., 2002; Do et al., 2014) with a slight modification. In brief, $0.5 \mathrm{ml}$ of sample solution or the standard solution were mixed in $1.5 \mathrm{ml}$ methanol, $0.1 \mathrm{ml} 10 \%$ aluminum chloride, $0.1 \mathrm{ml}$ of $1 \mathrm{M}$ sodium acetate, and $2.8 \mathrm{ml}$ aqua DM (double-distilled water). The mixture was incubated for 30 minutes at the room temperature, and absorbance was measured at $434 \mathrm{~nm}$ optimum wavelength. Quercetin solution $(3,4,5,6,7$, and $8 \mu \mathrm{g} / \mathrm{ml}$, respectively) was used as standards.

The yield of TFC in extract sample was examined using equation formula of standards $\left(Y=0.0568 X+0.0576\right.$ and $R^{2}=$ 0.9992 , where $Y$ is the yield of TFC and $X$ is the absorbance), and the result was expressed as milligram quercetin equivalent per gram extract (mg QE/g extract).

\section{Lipoxygenase inhibitory activity assay}

The lipoxygenase inhibitory activity (LIA) assay was performed according to the study reported by Dzoyem et al. (2015). Briefly, a 10- $\mu 1$ extract and baicalein solution were added $1,690 \mu \mathrm{l}$ of $0.2-\mathrm{M}$ borate buffer solution, $1,000 \mu \mathrm{l}$ of $300 \mu \mathrm{M}$ linoleic acid substrate solution, and the mixture was incubated for 10 minutes at $25^{\circ} \mathrm{C}$. After the incubation, the mixture was added to $300 \mu \mathrm{l}$ of $1,000 \mathrm{unit} / \mathrm{ml}$ lipoxygenase solution and was incubated again for 15 minutes at $25^{\circ} \mathrm{C}$. Then, the sample solution was added to $1,000 \mu 1$ methanol, and the absorbance was measured at $234 \mathrm{~nm}$ using a spectrophotometer UV. Percentage of LIA was examined using equation formula as follows:

$$
\% \text { Inibition }=\frac{(A-B)-(C-D)}{(A-B)} \times 100 \%
$$

where $A$ is the absorbance of the blank solution with an enzyme; $B$ is the absorbance of blank solution without enzyme; $C$ is the absorbance of the sample solution with an enzyme; and $D$ is the absorbance of sample solution without enzyme.

\section{Optimization of the IL-MAE method by response surface methodology}

IL-MAE method optimization was conducted using response surface methodology (RSM) to estimate the interaction of

Table 1. The parameters optimization of the IL-MAE method using RSM with Box-Behnken design.

\begin{tabular}{llcccc}
\hline \multirow{2}{*}{ Factors } & Unit & Symbol & \multicolumn{4}{c}{ Range and level } \\
& & & $-\mathbf{1}$ & $\mathbf{0}$ & $\mathbf{1}$ \\
\hline Liquid-solid ratio & $\mathrm{ml} / \mathrm{g}$ & $\mathrm{A}$ & 30 & 40 & 50 \\
Extraction time & minutes & $\mathrm{B}$ & 5 & 15 & 25 \\
$\begin{array}{l}\text { [BMIM]Br } \\
\text { concentration }\end{array}$ & $\mathrm{mol} / \mathrm{C}$ & $\mathrm{C}$ & 1 & 2 & 3 \\
\hline
\end{tabular}




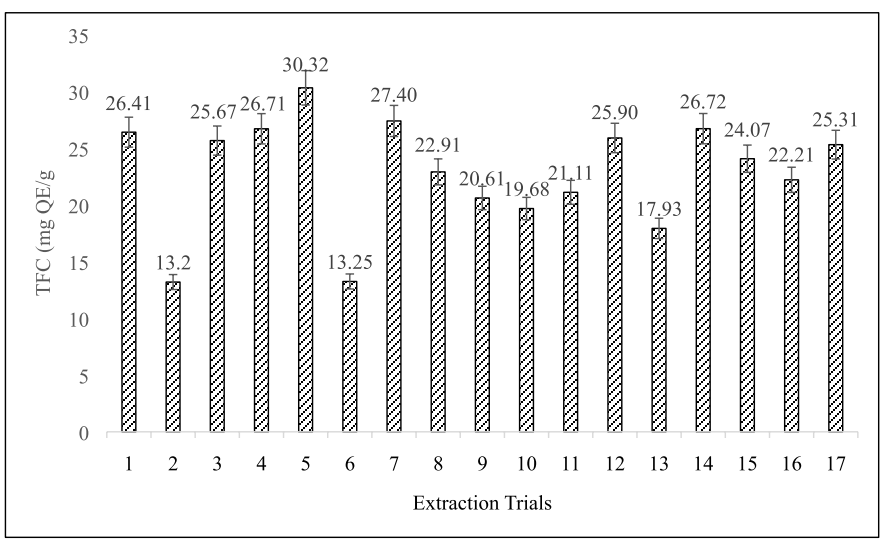

Figure 1. TFC of each extract using IL-MAE method.

process and factors parameters (independent parameters) against the TFC and LIA (dependent parameters). Box-Behnken design (tree-factor-three level) was used in this study, with 17 trials (in triplicate) for the extraction parameters optimization (Table 1). A regression model was examined with a multilinear quadratic model using Design-Expert v10 software.

\section{RESULTS AND DISCUSSION}

\section{Extraction process and pre-optimization}

The extraction process was performed using the IL-MAE method to obtain the optimum extraction on total flavonoid content (TFC) and LIA from green grass jelly leaves. Pre-optimization was conducted with some parameters variable condition including extraction time, liquid-solid ratio, and [BMIM]Br concentration to know the best condition. In this study, each parameter's variable was selected (Table 1) based on literature (Fan et al., 2012; Xu et al., 2012).

\section{Total flavonoid content determination}

Based on the result of total flavonoid content (TFC) determination (as can be seen in Fig. 1) demonstrated that the maximum of TFC (30.32 mg QE/g) was obtained from fifth trials. On the other hand, the lowest of TFC (13.20 mg QE/g) showed in second trials. Based on different combination of parameter variable at the experimental design, showed extraction time effect of TFC on the range from 5 to 25 minutes performed to obtain the optimal of extraction condition and the optimum of extraction time obtained for 15 minutes extraction time. Regarding liquidsolid ratio, the maximum of TFC was obtained at $40 \mathrm{ml} / \mathrm{g}$ with the range from 30 to $50 \mathrm{ml} / \mathrm{g}$ the increase of rate (after $40 \mathrm{ml} / \mathrm{g}$ ) led to a decrease on the TFC. Meanwhile, [BMIM]Br concentration effect of TFC extraction on the range from 1 to $3 \mathrm{~mol} / 1$ conducted to give the optimal concentration and the optimum concentration obtained at $2 \mathrm{~mol} / \mathrm{l}$.

\section{Determination of lipoxygenase inhibitory activity}

The preliminary test was performed to obtain the optimum conditions in the LIA assay using some parameters including the $\mathrm{pH}$ buffer of the boric acid solution, the linoleic acid substrate, and the lipoxygenase enzyme according to literature (Kumari et al., 2011; Xu et al., 2012). In this study, the

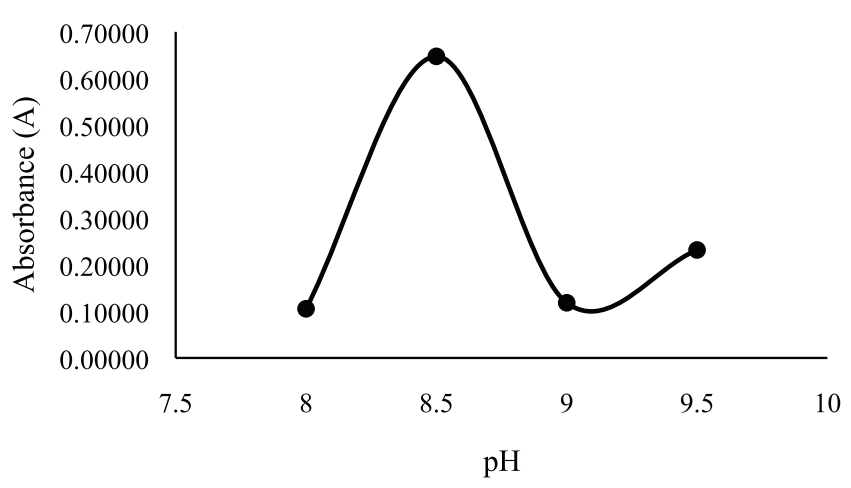

A

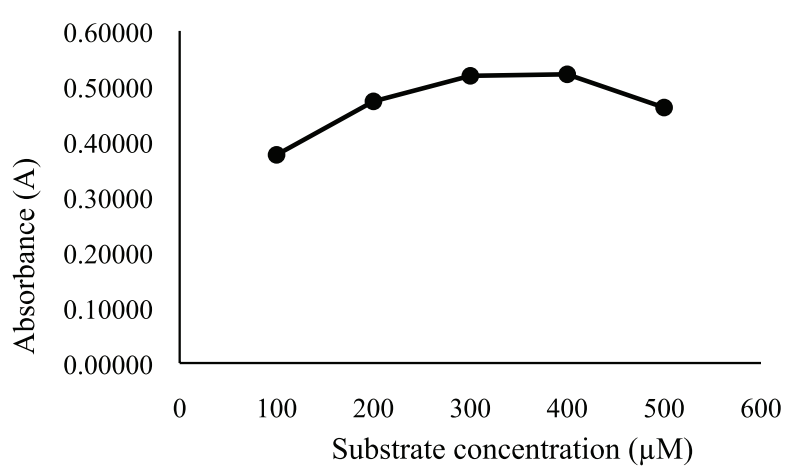

B

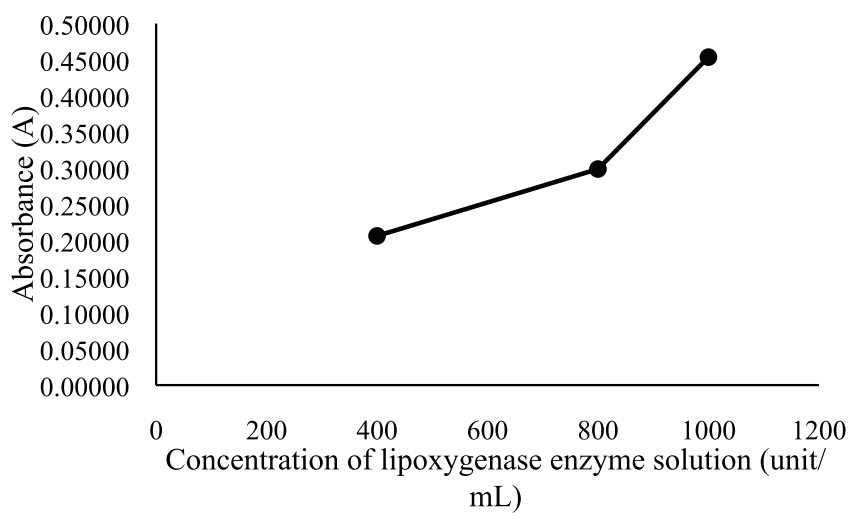

C

Figure 2. The optimum conditions of lipoxygenase activity inhibition assay. (A) The $\mathrm{pH}$ buffer of the boric acid solution, (B) the linoleic acid substrate, and (C) the lipoxygenase enzyme.

optimization of $\mathrm{pH}$ performed on 8.0, 8.5, 9.0, and 9.5 and the optimum condition was obtained at $\mathrm{pH} 8.5$ (Fig. 2A). Optimization of the linoleic acid substrate solution was conducted to determine the optimum substrate concentration, when binding correctly with the enzyme. Based on the previous study, Xu et al. (2012) used a $300 \mu \mathrm{M}$ substrate solution and Kumari et al. (2011) used a 250$\mu \mathrm{M}$ substrate solution. The optimization of the substrate solution 
Table 2. Results of lipoxygenase inhibitory activity by baicalein.

\begin{tabular}{|c|c|c|c|c|c|c|c|c|c|}
\hline \multirow[b]{2}{*}{$\begin{array}{c}\text { Concentration } \\
(\mu \mathrm{g} / \mathrm{ml})\end{array}$} & \multicolumn{4}{|c|}{ Absorbance } & \multirow[b]{2}{*}{$(a-b)$} & \multirow[b]{2}{*}{$(c-d)$} & \multirow[b]{2}{*}{$\begin{array}{c}\% \\
\text { Inhibition }\end{array}$} & \multirow[b]{2}{*}{$\begin{array}{c}\text { Mean of } \% \\
\text { Inhibition } \pm \\
\text { STDEV }\end{array}$} & \multirow[b]{2}{*}{ Regression equation } \\
\hline & $\begin{array}{c}\text { Blank } \\
\text { (a) }\end{array}$ & $\begin{array}{c}\text { Blank } \\
\text { control } \\
\text { (b) }\end{array}$ & $\begin{array}{c}\text { Baicalein } \\
\text { (c) }\end{array}$ & $\begin{array}{l}\text { Baicalein } \\
\text { control } \\
\text { (d) }\end{array}$ & & & & & \\
\hline \multirow{3}{*}{0.100} & \multirow{3}{*}{0.8536} & \multirow{3}{*}{0.4435} & 0.8802 & 0.6069 & \multirow{3}{*}{0.4101} & 0.2733 & 33.36 & \multirow{3}{*}{$\begin{array}{l}32.05 \pm \\
2.1642\end{array}$} & \\
\hline & & & 0.8818 & 0.6080 & & 0.2738 & 33.23 & & \\
\hline & & & 0.8894 & 0.6005 & & 0.2889 & 29.55 & & \\
\hline \multirow{3}{*}{0.125} & \multirow{3}{*}{0.8536} & \multirow{3}{*}{0.4435} & 0.7915 & 0.5541 & \multirow{3}{*}{0.4101} & 0.2374 & 42.12 & \multirow{3}{*}{$\begin{array}{c}42.47 \pm \\
0.3172\end{array}$} & \\
\hline & & & 0.7922 & 0.5567 & & 0.2355 & 42.56 & & \\
\hline & & & 0.7938 & 0.5589 & & 0.2348 & 42.73 & & \\
\hline \multirow{3}{*}{0.150} & \multirow{3}{*}{0.8762} & \multirow{3}{*}{0.4650} & 0.7076 & 0.4979 & \multirow{3}{*}{0.4112} & 0.2098 & 49.00 & \multirow{3}{*}{$\begin{array}{c}49.14 \pm \\
0.4974\end{array}$} & \\
\hline & & & 0.7078 & 0.4970 & & 0.2108 & 48.73 & & $y=0.7864 x+1.8726$ \\
\hline & & & 0.7038 & 0.4969 & & 0.2069 & 49.69 & & $R^{2}=0.9975$ \\
\hline \multirow{3}{*}{0.200} & \multirow{3}{*}{0.8982} & \multirow{3}{*}{0.4283} & 0.7157 & 0.5568 & \multirow{3}{*}{0.4699} & 0.1589 & 66.18 & \multirow{3}{*}{$\begin{array}{c}65.55 \pm \\
1.1828\end{array}$} & $r=0.9987$ \\
\hline & & & 07123 & 0.5539 & & 0.1584 & 66.29 & & \\
\hline & & & 0.7134 & 0.5451 & & 0.1683 & 64.19 & & \\
\hline \multirow{3}{*}{0.225} & \multirow{3}{*}{0.8982} & \multirow{3}{*}{0.4283} & 0.5871 & 0.4594 & \multirow{3}{*}{0.4699} & 0.1278 & 72.81 & \multirow{3}{*}{$\begin{array}{c}72.07 \pm \\
0.6836\end{array}$} & \\
\hline & & & 0.5906 & 0.4588 & & 0.1318 & 71.94 & & \\
\hline & & & 0.5927 & 0.4586 & & 0.1341 & 71.46 & & \\
\hline \multirow{3}{*}{0.250} & \multirow{3}{*}{0.8650} & & 0.5803 & 0.4870 & & 0.0933 & 79.81 & & \\
\hline & & 0.4028 & 0.5747 & 0.4863 & 0.4622 & 0.0884 & 80.87 & $\begin{array}{c}80.24 \pm \\
0.5537\end{array}$ & \\
\hline & & & 0.5802 & 0.4880 & & 0.0922 & 80.05 & & \\
\hline
\end{tabular}

was done on the concentration of $100,200,300,400$, and 500 $\mu \mathrm{M}$. The optimum condition was $300 \mu \mathrm{M}$ (Fig. 2B), whereas, the optimization of enzyme solution was performed using several concentrations of 400,800 , and 1,000 unit/ml, and the optimum solution was 1,000 unit/ml (Fig. 2C).

The LIA assay was conducted using baicalein as a standard (Putri et al., 2017). Baicalein is a flavonoid from flavonols groups (Kusmardiyani et al., 2014) that has the capability to inhibit the lipoxygenase activity due to hydroperoxy-octadecadienoate (HPOD) was not formed (Putri et al., 2017). The higher the baicalein content, the less HPOD was formed so that, higher the inhibition percentage (Putri et al., 2017). Table 2 demonstrates that the baicalein concentration from 0.1 to $0.25 \mu \mathrm{g} / \mathrm{ml}$ can inhibit from $33.36 \%$ to $80.05 \%$ with the linear regression equation of $y$ $=0.7864 x+1.8526\left(R^{2}=0.9975\right)$. In this study, the $\mathrm{IC}_{50}$ value of baicalein was $0.2 \mu \mathrm{g} / \mathrm{ml}$ which indicates that the enzyme works well. Figure 3 showes the highest of the LIA in 12th trials with an inhibitory percentage of $69.29 \%$. Although the highest levels of LIA were not at fifth trials (where the most top of the TFC) and 12 th trials also used the optimum condition variable include 40 $\mathrm{ml} / \mathrm{g}$ liquid-solid ratio, 15 minutes extraction time, and $2 \mathrm{~mol} / \mathrm{l}$ [BMIM]Br concentration.

\section{Optimization of the IL-MAE method}

Three factors with three levels $(-1,0,+1)$, including liquid-solid ratio $(30,40$, and $50 \mathrm{ml} / \mathrm{g})$, extraction time $(5,15$, and 25 minutes), and [BMIM] Br concentration (1, 2, and $3 \mathrm{~mol} / \mathrm{l})$ were optimized using RSM with Box-Behnken design. Data analysis was performed to obtain the optimum condition for extraction of flavonoid using the IL-MAE method and LIA, the specific protocols of experimental design of parameters conditions are shown in

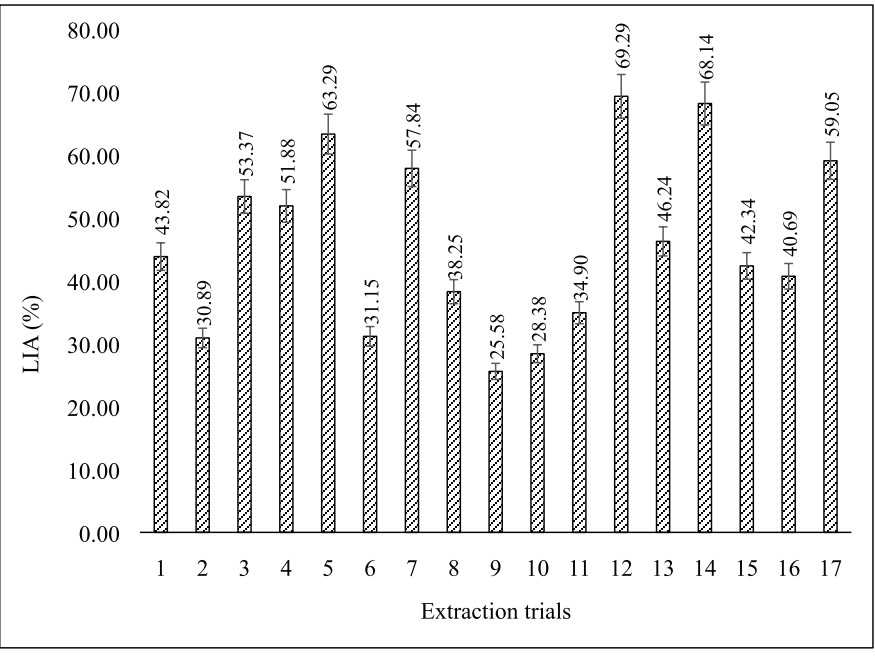

Figure 3. Lipoxygenase inhibitory activity of each extract.

Table 1. Based on the obtained results using RSM analysis with Design Expert v10 software, in Figure 4, demonstrated the threedimension contour of the response surface for interaction between the factor and process parameters.

To further study the response surface plot for the TFC and LIA of the obtained extracts as a function were analyzed and developed based on the equation formula from RSM analysis results to determine the optimum condition, including liquid-solid ratio to extraction time ([BMIM]Br concentration $=2 \mathrm{~mol} / \mathrm{l})$, liquid-solid ratio to [BMIM]Br concentration (extraction time $=15$ minutes), and extraction time to [BMIM] $\mathrm{Br}$ concentration (liquid-solid ratio $=40 \mathrm{ml} / \mathrm{g}$ ). The different experimental designs 

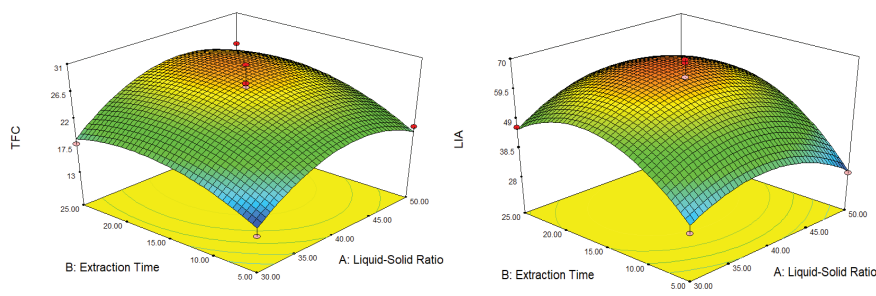

A
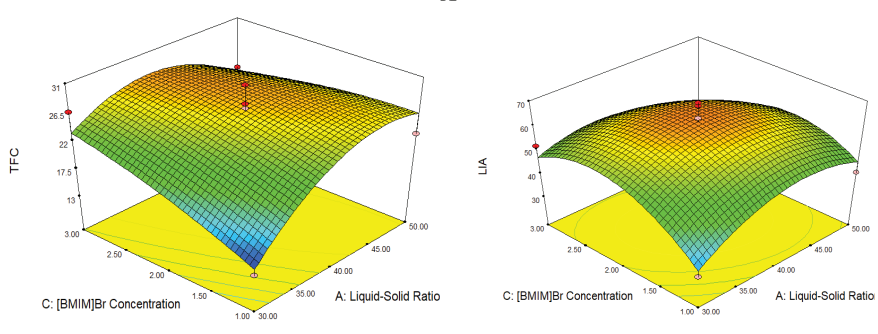

B
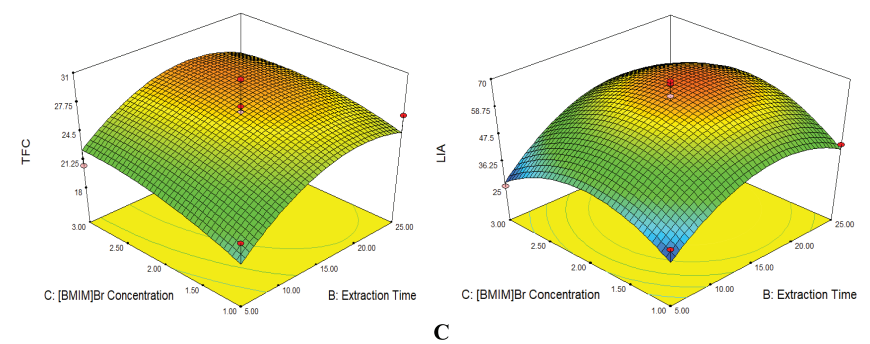

Figure 4. Three dimensional of the contour plot. (A) Interaction of liquid-solid ratio and extraction time. (B) Interaction of liquid-solid ratio and [BMIM] $\mathrm{Br}$ concentration. (C) Interaction of extraction time and [BMIM] Br concentration.

Table 3. Experimental design of parameters condition for average TFC and LIA by RSM with Box-Behnken design.

\begin{tabular}{cccccc}
\hline Run/ & $\begin{array}{c}\text { Factor A: } \\
\text { Liquid- } \\
\text { Trials } \\
\text { (mL/g) }\end{array}$ & $\begin{array}{c}\text { Factor B: } \\
\text { Extraction } \\
\text { time } \\
\text { (minutes) }\end{array}$ & $\begin{array}{c}\text { Factor C: } \\
\text { [BMIM]Br } \\
\text { concentration } \\
\text { (mol/L) }\end{array}$ & $\begin{array}{c}\text { Total } \\
\text { Flavonoid } \\
\text { Content } \\
\text { (TFC) } \\
\text { (mg QE/g) }\end{array}$ & LIA (\%) \\
\hline 1 & $40(0)$ & $25(1)$ & $1(-1)$ & 26.41 & 43.82 \\
2 & $30(-1)$ & $15(0)$ & $1(-1)$ & 13.19 & 30.89 \\
3 & $50(1)$ & $25(1)$ & $2(0)$ & 25.67 & 53.37 \\
4 & $30(-1)$ & $15(0)$ & $3(1)$ & 26.67 & 51.88 \\
5 & $40(0)$ & $15(0)$ & $2(0)$ & 30.32 & 63.29 \\
6 & $30(-1)$ & $5(-1)$ & $2(0)$ & 13.25 & 31.15 \\
7 & $40(0)$ & $15(0)$ & $2(0)$ & 27.40 & 57.84 \\
8 & $50(1)$ & $15(0)$ & $3(1)$ & 22.91 & 38.25 \\
9 & $40(0)$ & $5(-1)$ & $3(1)$ & 20.61 & 25.58 \\
10 & $50(1)$ & $5(-1)$ & $2(0)$ & 19.68 & 28.38 \\
11 & $40(0)$ & $5(-1)$ & $1(-1)$ & 21.11 & 34.90 \\
12 & $40(0)$ & $15(0)$ & $2(0)$ & 25.90 & 69.29 \\
13 & $30(-1)$ & $25(1)$ & $2(0)$ & 17.93 & 46.24 \\
14 & $40(0)$ & $15(0)$ & $2(0)$ & 26.72 & 68.14 \\
15 & $40(0)$ & $25(1)$ & $3(1)$ & 24.07 & 42.34 \\
16 & $50(+1)$ & $15(1)$ & $1(-1)$ & 22.21 & 40.69 \\
17 & $40(0)$ & $15(0)$ & $2(0)$ & 25.31 & 59.05 \\
\hline & & & & & \\
\hline
\end{tabular}

of the extraction process with response (TFC and LIA) are demonstrated in Table 3. The obtained data were calculated by multilinear regression analysis based on the response surface. The final model of TFC and LIA from green grass jelly leaf $(C$. barbata) was given by: $\mathrm{TFC}=2.43 \mathrm{~A}+2.43 \mathrm{~B}+1.42 \mathrm{C}+0.33 \mathrm{AB}$ $-3.20 \mathrm{AC}-0.46 \mathrm{BC}-4.90 \mathrm{~A}^{2}-3.10 \mathrm{~B}^{2}-0.98 \mathrm{C}^{2}+27.13$ and LIA $=0.066 \mathrm{~A}+8.22 \mathrm{~B}+0.97 \mathrm{C}+2.47 \mathrm{~B}-5.86 \mathrm{AC}+1.96 \mathrm{BC}-9.99 \mathrm{~A}^{2}$ $-13.75 \mathrm{~B}^{2}-13.11 \mathrm{C}^{2}+63.53$, respectively.

Table 4 demonstrates the significant model with a $F$-value of 3.90 . There is only a $4.33 \%$ chance that a "Model $F$-value" this large could occur due to noise. The value of "Prob $>F^{\prime}$ less than 0.0500 indicated model terms were significant.

Table 4. Test of ANOVA significance for regression coefficient by quadratic model with TFC as a response surface value.

\begin{tabular}{cccccc}
\hline Source & $\begin{array}{c}\text { Sum of } \\
\text { squares }\end{array}$ & df & $\begin{array}{c}\text { Mean } \\
\text { Square }\end{array}$ & $\boldsymbol{F}$ value & $\begin{array}{c}\boldsymbol{p} \text {-value } \\
\text { Prob }>\boldsymbol{F}\end{array}$ \\
\hline Model $^{\mathrm{a}}$ & 309.85 & 9 & 34.43 & 3.90 & 0.0433 \\
A & 47.19 & 1 & 47.19 & 5.34 & 0.0541 \\
B & 47.19 & 1 & 47.19 & 5.34 & 0.0541 \\
C & 16.07 & 1 & 16.07 & 1.82 & 0.2193 \\
AB & 0.43 & 1 & 0.43 & 0.049 & 0.8319 \\
AC & 40.83 & 1 & 40.83 & 4.62 & 0.0686 \\
BC & 0.85 & 1 & 0.85 & 0.096 & 0.7659 \\
A $^{2}$ & 101.15 & 1 & 101.15 & 11.45 & 0.0117 \\
B $^{2}$ & 40.37 & 1 & 40.37 & 4.57 & 0.0699 \\
$C^{2}$ & 4.07 & 1 & 4.07 & 0.46 & 0.5188 \\
Residual & 61.83 & 7 & 8.83 & & \\
Lack of Fit & 46.59 & 3 & 15.53 & 4.08 & 0.1041 \\
Pure Error & 15.24 & 4 & 3.81 & & \\
Cor Total & 371.68 & 16 & & & \\
\hline
\end{tabular}

a: A model where $A$ is the liquid-solid ratio $(\mathrm{ml} / \mathrm{g}), B$ is extraction time (minutes), and $C$ is [BMIM]Br concentration.

Table 5. Test of ANOVA significance for regression coefficient by quadratic model with LIA as a response surface value.

\begin{tabular}{cccccc}
\hline Source & $\begin{array}{c}\text { Sum of } \\
\text { squares }\end{array}$ & df & $\begin{array}{c}\text { Mean } \\
\text { square }\end{array}$ & $\boldsymbol{F}$ value & $\begin{array}{c}\boldsymbol{p} \text {-value } \\
\text { Prob }>\boldsymbol{F}\end{array}$ \\
\hline Model $^{\mathrm{a}}$ & $2,888.09$ & 9 & 320.90 & 9.03 & 0.0042 \\
$\mathrm{~A}$ & 0.035 & 1 & 0.035 & $9.881 \mathrm{E}-004$ & 0.9758 \\
B & 540.55 & 1 & 540.55 & 15.21 & 0.0059 \\
C & 7.51 & 1 & 7.51 & 0.21 & 0.6597 \\
$\mathrm{AB}$ & 24.50 & 1 & 24.50 & 0.69 & 0.4337 \\
AC & 137.24 & 1 & 137.24 & 3.86 & 0.0901 \\
BC & 15.37 & 1 & 15.37 & 0.43 & 0.5318 \\
$\mathrm{~A}^{2}$ & 419.94 & 1 & 419.94 & 11.82 & 0.0109 \\
$\mathrm{~B}^{2}$ & 796.54 & 1 & 769.54 & 22.42 & 0.0021 \\
$\mathrm{C}^{2}$ & 723.87 & 1 & 723.87 & 20.37 & 0.0028 \\
Residual & 248.74 & 7 & 35.53 & & \\
Lack of Fit & 141.98 & 3 & 47.33 & 1.77 & 0.2911 \\
Pure Error & 106.75 & 4 & 26.69 & & \\
Cor Total & $3,136.83$ & 16 & & & \\
\hline
\end{tabular}

a: A model where $A$ is the liquid-solid ratio $(\mathrm{ml} / \mathrm{g}$ ), $B$ is extraction time (minutes), and $C$ is [BMIM]Br concentration. 
Table 6. The credibility of the regression equations.

\begin{tabular}{lcc}
\hline Index mark $^{\mathbf{a}}$ & Average extraction of TFC & Average extraction of LIA \\
\hline Std. Dev & 2.97 & 5.96 \\
Mean & 22.90 & 46.18 \\
C.V. (\%) & 12.98 & 12.91 \\
PRESS & 769.25 & 2438.52 \\
R-Squared & 0.8336 & 0.9207 \\
Adjust R-Squared & 0.6198 & 0.8188 \\
Predicted R-Squared & -1.0696 & 0.2226 \\
Adequacy Precision & 5.671 & 7.891 \\
\hline
\end{tabular}

${ }^{a}$ The results were obtained using Design Expert v10.03 software.

The "Lack of Fit $F$-value" of 4.08 implies the "Lack of Fit" is not significant relative to the pure error. There is a $10.41 \%$ chance that a "Lack of Fit F-value" this large could occur due to noise and non-significant "Lack of Fit" is good.

In Table 5, the model $F$-value of 9.03 implies the model is significant. There is only a $0.42 \%$ chance that a "Model F-values" this large could occur due to noise. The value of "Prob $>F$ " less than 0.05 indicate model terms are significant. The significance of the value of 1.77 "Lack of Fit" with $F$ value $>0.05$ is not significant relative to the pure error. There is a $29.11 \%$ chance that a "Lack of Fit F-value" this large could occur due to noise.

Table 6 shows the credibility of regression equations, the correlation coefficient " $R$-Squared" of 0.8416 (TFC) and 0.9207 (LIA) were obtained implies this model can express correlation of model more than $80 \%$ and $90 \%$, respectively. A negative "Pred $R$-Squared" of TFC implied that the overall mean might be a better predictor of response than the current model, whereas the "Pred $R$-Squared" of LIA (0.2226) is not as close to the "Adj $R$-Squared" of 0.8188 as one might normally expect. "Adequacy Precision" measures the signal-to-noise ratio. The ratio of 5.671 (TFC) and 7.891 (LIA) indicates an adequate signal, where both ratios greater than four was desirable.

Based on the results of RSM analysis, the optimum condition was suggested with the parameter variable as follows: liquid-solid ratio of $38.21 \mathrm{ml} / \mathrm{g}$, extraction time of 17 minutes, and [BMIM]Br concentration of $1.76 \mathrm{~mol} / \mathrm{l}$ with TFC and LIA prediction of $26.38 \pm 1.30 \mathrm{mg}$ QE/g sample and $62.8558 \% \pm$ $2.62 \%$, respectively.

\section{CONCLUSION}

Based on the results, the design of the IL-MAE method to TFC extraction and LIA from Green grass jelly leaf $(C$. barbata) has attempted. The optimum condition of the IL-MAE method was obtained the parameter variables include 17 minutes extraction time, $1.76 \mathrm{~mol} / \mathrm{l}$ [BMIM] $\mathrm{Br}$ concentration, and 38.21 $\mathrm{ml} / \mathrm{g}$ liquid-solid ratio with the TFC prediction value of $29.07 \mathrm{mg}$ QE/g sample.

This research was an early stage to develop the extraction method to obtain the target compound from natural products plant in an efficient, rapid, and environmental friendly. Future research should be performed for the optimization of extraction procedure in other parameter variables, pilot scale, isolation, and identification of flavonoid content (mainly the active target compound) from this plant by using green chemistry approaches.

\section{CONFLICT OF INTEREST}

All authors declare that they have no conflict of interest.

\section{FUNDING}

This study was funded by Directorate of Research and Humanity Engagement (DRPM), Universitas Indonesia via grant "Hibah PITTA 2017."

\section{REFERENCES}

Ahmad I, Yanuar A, Mulia K, Mun'im A. Application of ionic liquid as a green solvent for polyphenolics content extraction of Peperomia pellucida (L) Kunth Herb. J Young Pharm, 2017a; 9:486-90.

Ahmad I, Yanuar A, Mulia K, Mun'im A. Optimization of ionic liquid-based microwave-assisted extraction of polyphenolic content from Peperomia pellucida (L) Kunth using response surface methodology. Asian Pac J Trop Biomed, 2017b; 7:660-5.

Akula US, Odhav B. In vitro 5-lipoxygenase inhibition of polyphenolic antioxidants from undomesticated plants of South Africa. J Med Plants Res, 2008; 2:207-12.

Arkarapanthu A, Chavasit V, Sungpuag P, Phuphathanaphong L. Gel extracted from Khruea-Ma-Noi (Cyclea Barbata Miers) leaves: chemical composition and gelation properties. J Sci Food Agr, 2005; 85:1741-9.

Azmir J, Zaidul ISM, Rahman MM, Sharif KM, Mohamed A, Sahena F, Jahurul MHA, Ghafoor K, Norulaini NAN, Omar AKM. Techniques for extraction of bioactive compounds from plant materials: a review. J Food Eng, 2013; 117:426-36.

Baba SA, Malik SA. Determination of total phenolic and flavonoid content, antimicrobial and antioxidant activity of a root extract of Arisaema Jacquemontii Blume. J Taibah Univ Sci, 2015; 9:449-54.

Bubalo MC, Radošević K, Redovniković IR, Halambek J, Srček VG. A brief overview of the potential environmental hazards of ionic liquids. Ecotoxicol Environ Saf, 2014; 99:1-12.

Carda-broch S, Berthod A, Ruiz-Angel MJ. Ionic liquids in separation techniques. J Chromatogr A, 2008; 1184:6-18.

Chang C-C, Yang M-H, Wen H-M. Estimation of total flavonoid content in propolis by two complementary colorimetric methods. J Food Drug Anal, 2002; 10:178-82.

Chemat F, Vian MA. Green chemistry and sustainable technology: alternative solvents for natural products extraction. Springer US, Heidelberg, New York, Dordrecht, London, 2014.

Chemat F, Vian MA, Cravotto G. Green extraction of natural products: concept and principles. Int J Mol Sci, 2012; 13:8615-27.

Do QD, Angkawijaya AE, Tran-Nguyen PL, Huynh LH, Soetaredjo FE, Ismadji S, Ju YH. Effect of extraction solvent on total phenol content, total flavonoid content, and antioxidant activity of Limnophila Aromatica. J Food Drug Anal, 2014; 22:296-302.

Dzoyem JP, Lannang AM, Fouotsa H, Mbazoa CD, Nkengfack AE, Sewald N, Eloff JN. Anti-inflammatory activity of benzophenone and xanthone derivatives isolated from Garcinia (Clusiaceae) species Phytochem Lett, 2015; 14:153-8.

Fan JP, Cao J, Zhang XH, Huang JZ, Kong T, Tong S, Tian ZY, Xie YL, Xu R, Zhu JH. Optimization of ionic liquid-based ultrasonicassisted extraction of puerarin from Radix Puerariae Lobatae by response surface methodology. Food Chem, 2012; 135:2299-306.

Hertanto BS, Kartikasari LR, Swastike W, Cahyadi M, Yuliani A, Nuhriawangsa AMP. Physical properties of milk Cincau curd on different concentrations of green cincau leaf (Cyclea Barbata L. Miers). IOP Conf Series Mat Sci Eng, 2017; 193:2-6. 
Kumar S, Pandey AK. Chemistry and biological activities of flavonoids: an overview. Sci World J, 2013; 2013:1-16.

Kumari R, Meyyappan A, Selvamani P, Mukherjee J, Jaisankar P. Lipoxygenase inhibitory activity of crude bark extracts and isolated compounds from Commiphora Berryi. J Ethnopharmacol, 2011; 138:256-9.

Kusmardiyani S, Insanu M, Al Asyhar M. Effect a glycosidic flavonol isolated from green grass jelly (Cyclea barbata Miers) leaves. Proc Chem, 2014; 13:194-7.

Medzhitov R. Origin and physiological roles of inflammation. Nature, 2008; 454:428-35.

Putri NL, Elya B, Puspitasari N. Antioxidant activity and lipoxygenase inhibition test with total flavonoid content from Garcinia kydia Roxburgh leaves extract. Pharmacogn J, 2017; 9:280-4.

Sahasakul Y, Thiyajai P, Kriengsinyos W, Charoenkiatkul S. Nutrients and phenolic acids in Krung Ba Dan (Cyclea barbata Miers) leaves and aqueous extract from Ubon Ratchathani Province. J Sci Technol Ubon Ratchathani Univ, 2015; 17:1-9.

Siregar IM, Miladiyah I. Protective effects of Cyclea barbata Miers leaves against aspirin-induced gastric ulcer in Mice. Universa Med, 2011; 30:88-94.

Tang B, Bi W, Tian M, Row KH. Application of ionic liquid for extraction and separation of bioactive compounds from plants. J Chromatogr B, 2012; 904:1-21.

Tang B, Lee YJ, Lee YR, Row KH. Examination of 1-methylimidazole series ionic liquids in the extraction of flavonoids from Chamaecyparis obtuse leaves using a response surface methodology. J Chromatogr B, 2013; 933:8-14.

Wang SY, Yang L, Zu YG, Zhao CJ, Sun XW, Zhang L, Zhang ZH. Design and performance evaluation of ionic-liquids-based microwaveassisted environmentally friendly extraction technique for camptothecin and 10-hydroxycamptothecin from samara of Camptotheca acuminata. Indust Eng Chem Res, 2011; 50:13620-7.
Wei W, Fu YJ, Zu YG, Wang W, Luo M, Zhao CJ, Li CY, Zhang L, Wei ZF. Ionic liquid-based microwave-assisted extraction for the determination of flavonoid glycosides in Pigeon Pea leaves by high-performance liquid chromatography-diode array detector with pentafluorophenyl column. J Separat Sci, 2012; 35:2875-83.

Xu W, Chu K, Li H, Zhang Y, Zheng H, Chen R, Chen L. Ionic liquid-based microwave-assisted extraction of flavonoids from Bauhinia championii (Benth.) Benth. Molecules, 2012; 17:14323-35.

Yuliarti O, Chong SY, Goh KKT. Physicochemical properties of pectin from green jelly leaf (Cyclea barbata Miers). Int J Biol Macromol, 2017; 103:1146-54.

Zhang Q, Zhao S-H, Chen J, Zhang LW. Application of ionic liquid-based microwave-assisted extraction of flavonoids from Scutellaria baicalensis Georgi. J Chromatogr B, 2015; 1002:411-7.

Zhang Y, Liu Z, Li Y, Chi R. Optimization of ionic liquid-based microwave-assisted extraction of isoflavones from Radix Puerariae by response surface methodology. Separat Purificat Technol, 2014; 129:71-9.

\section{How to cite this article:}

Ahmad I, Elya B, Ismail YI, Noviani A, Kuncoro H, Maryono, Ambarwati NSS. Design of ionic liquid-based microwaveassisted extraction of flavonoids from Cyclea barbata Miers. and its lipoxygenase inhibitory activity. J Appl Pharm Sci, 2020; 10(04):001-007. 